Nur'Aini, S. University Students' Learning Disruption and

Affordance in a Contested Learning Environment

\title{
University Students' Learning Disruption and Affordance in a Contested Learning Environment
}

Siti Nur'Aini

Universitas PGRI Semarang, Indonesia

Email: sitinuraini@upgris.ac.id

Received : 2021-06-10

Revised : 2021-07-19

Accepted : 2021-08-30

$10.46303 /$ ressat.2021.23

How to cite this paper: Nur'Aini, S. (2021). University Students' Learning Disruption and Affordance in a Contested Learning Environment. Research in Social Sciences and Technology, 6(3), 25-44. https://doi.org/10.46303/ressat.2021.23

This is an Open Access article distributed under the terms of the Creative Commons Attribution 4.0 International license (https://creativecommons.org/licenses/by/4.0/).

\section{Abstract}

This study investigates how university students engage with their learning affordances in a contested environment due to the Coronavirus pandemic. This qualitative research employed a case study approach involving 136 participants. Data analysis was conducted using qualitative analysis as a circular process to describe, classify, and perceive the phenomenon and how the learning, affordances, and society were interconnected. The main framework of the research was the theory of affordance and how it was available for university students in their learning environment that changed due to the COVID-19 pandemic. Data were collected in the first semester of 2020 through an online survey on Google form. The findings indicate the importance of the social environment to provide affordance for the students to adjust with them. Four kinds of affordances emerged from the study; internet affordance, assignment affordance, domestic affordance, and distance learning affordance. The role of the social environment is definitive in changing how students manage their affordances.

Keywords: Learning affordance; case study; contested environment; coronavirus pandemic; circular process.

\section{Introduction}

One of the key aspects of education is the society where education takes place. However, society can become a source of challenges in many aspects of life due to changes in the environment caused by natural disasters, political unrest, war, or a plague (Atmojo \& Nugroho, 2020; Palvia et al., 2018; Stone, 2019). When this happens, social and environmental issues become a source of controversy. Last year, the world was hit with a plague that disrupted education practice all over the globe. With the announcement from the WHO that COVID-19 was a global pandemic (Sohrabi et al., 2020), the government of many countries released laws to close the factories, malls, government offices, schools, and universities to prevent people 
Nur'Aini, S. University Students' Learning Disruption and

Affordance in a Contested Learning Environment

from gathering in large groups. The environment where schools used to be conducted was no longer safe, and it became contested due to the plague (Liu et al., 2020; Saltiel, 2017; Vladoiu \& Constantinescu, 2020). In many campuses across the globe, like in Hong Kong (Wong \& Moorhouse, 2020), Indonesia (Wajdi et al., 2020), India (Li \& Lalani, 2020), students and teachers were not permitted to have a direct interaction in the classroom as it could increase the risk of spreading the disease; thus, learning had to be conducted by distance or online (Pete, 2020; Purcell \& Hetrick, 2020).

In the history of education, face to face meeting with the teachers has been thought of as the critical factor in the success of education as it offered numerous social contexts where both students and teachers could interact without barriers (Daumiller et al., 2020; Li \& Lalani, 2020; Rapanta et al., 2020). The paramount of offline education was the direct contact between teachers and students, which inherently become absent as learning moved to an online platform. The migration from offline to online learning came with challenges for students and teachers worldwide because they had to study from home (Wilder-Smith \& Freedman, 2020).

This research paper aimed to respond to two research questions: what types of learning affordances were available within the contested environment because of COVID-19 and how they adapt to the changes in their society and learning contexts to overcome their learning challenges. This study considered the past and present situation of distance learning and how the environment changed the way learning was conducted and why it matters to understand what affordance is available to the learners in the disrupted and contested learning environment.

\section{Literature Review}

\section{Distance and Online Learning in Developing Countries}

The concepts of a face-to-face meeting in a classroom (Mueller, 2018) and distance learning (He et al., 2014) are familiar in the manner of teaching. Face-to-face meeting in a classroom has been going for as long as human existence and their need for education (Tao et al., 2016); however, recent years have witnessed the growing academic interest in implementing distance learning.

In recent years, a worldwide recognition of distance learning has been acknowledged (Kalimullina et al. 2021); for example, White $(2003,2014)$ and Nyoni (2014) described that Open University UK is among the world's biggest distance learning providers whose operation dates back to 1969. For their courses, course books, video and audio documentaries, audio activity cassettes, and transcripts of video - and audiocassettes were available to the learners. These learning tools are similar to what is used in China and Indonesia Open University, where learners read the hard copied materials sent by post, recorded lectures, and hard copy notes. Learners also used government-operated radio stations and TV programs to get materials (Nyoni, 2014; Stone, 2019). Other countries, such as Botswana and Tanzania (Perraton, 1985, p. 31), implemented distance learning to train their teachers. In a more sophisticated country like the US, distance learning was conducted with satellite and broadcasting technology (Nyoni, 2014). 
Nur'Aini, S. University Students' Learning Disruption and

Affordance in a Contested Learning Environment

There have been changes in how learning media in distance learning was delivered with the emergence of the internet. What used to be delivered in papers, notes, radio, or TV (Kidd, 2010; Sancristobal et al., 2012) has now transformed into an online platform where learners could download the materials, obtain the PDF documents, read them on-screen, or watch the tutorial online (Stone, 2019). Some course providers use the Learning Management System (LMS) to facilitate the learners to access theoretical content, join in a forum, and collect assignments (Sancristobal et al., 2012). Although the delivery method changed, one thing that stays within the online learning context is the learners' choices on responding to their environment.

Most learners are aware of why they chose online learning, although they could choose the offline one as most providers that offer online courses also provide the offline one. In online learning, they voluntarily enrolled in the course and picked when and how they wanted to learn, and decide what kind of support was available. They employ and utilize affordance in their learning because of their readiness to conduct online learning (Arthur-Nyarko et al., 2020). They know the implications (Nyoni, 2014) and benefit of online learning, such as there is no need for them to travel and leave the comfort of their home (Weidlich \& Bastiaens, 2019), they have plentiful online resources where they could do research and the freedom to manage their time (Zhu \& Bingham, 2010) and to gain the equal opportunities of online learning (Williams et al., 2021).

The current online learning situation for university students is different from the circumstance described above. Within the contested environment due to COVID-19, the preparedness and readiness of students are not known. Online learning was forced upon them because of the virus and government policy; thus, not everyone is prepared for it. Therefore, how students cope with the sudden change and how they conduct their learning is unknown. The way university students overcome the challenges and use affordances in their environment will become the focus and purpose of this study.

\section{Affordances}

The theory of affordance provides valuable insight into how human beings live in an environment that can support their physical and mental livelihood and wellbeing. The environment provides the good and the bad things that human beings need for their growth, and the things it provides are called affordances. A researcher in the field of affordances, Gibson (2015, p. 119), elaborates that "the affordances of the environment are what it offers the animal, what it provides or furnishes, either for good or for ill," which can be interpreted as the food, water, predator or prey to keep the ecosystem balanced. Norman (2002) emphasizes the importance of affordance on how an actor relies on their environment to carry out their intentions, plans, values, beliefs, and experiences. However, another researcher Laurillard (2002) demonstrated that affordances in the context of technologies have limitation and constraints which enable individuals to pause and analyze to understand their environment to meet their needs. In his analysis, Van Lier (2004) proposes a context-specific definition of affordances as the roots of the relationship between the person and the physical, social, and symbolic world, and he also defines the four levels of affordances as shown in Table 1. 
Nur'Aini, S. University Students' Learning Disruption and Affordance in a Contested Learning Environment

Table 1. Levels of Affordance (van Lier, 2004)

\begin{tabular}{cl}
\hline Level & Affordances \\
\hline 1 & Unmediated attachment between the organism and the environment \\
\hline 2 & Organism realizes the presence of affordance and engages it \\
\hline 3 & Participative control to the realization of affordance \\
\hline 4 & A critical point of view towards the affordance itself \\
\hline
\end{tabular}

Table 1 describes affordance levels from the simplest to the most complex relationship between affordances and the environment. The first level is described as an 'unmediated' attachment between the organism and the environment, which means that the environment has the possible affordances that the organism might or might not need. Meanwhile, a secondlevel affordance involves the organism who realizes the presence of affordances and engages it. A third level affordance, Van Lier (2004) adds the participative control to the realization of affordance, and level four affordance provides the critical point of view towards the affordance itself. The relationship between affordance in a context and how individuals/organisms understand it is shown in Figure 1 below:

Figure 1. The emergence of affordance (Van Lier, 2004, p. 92)

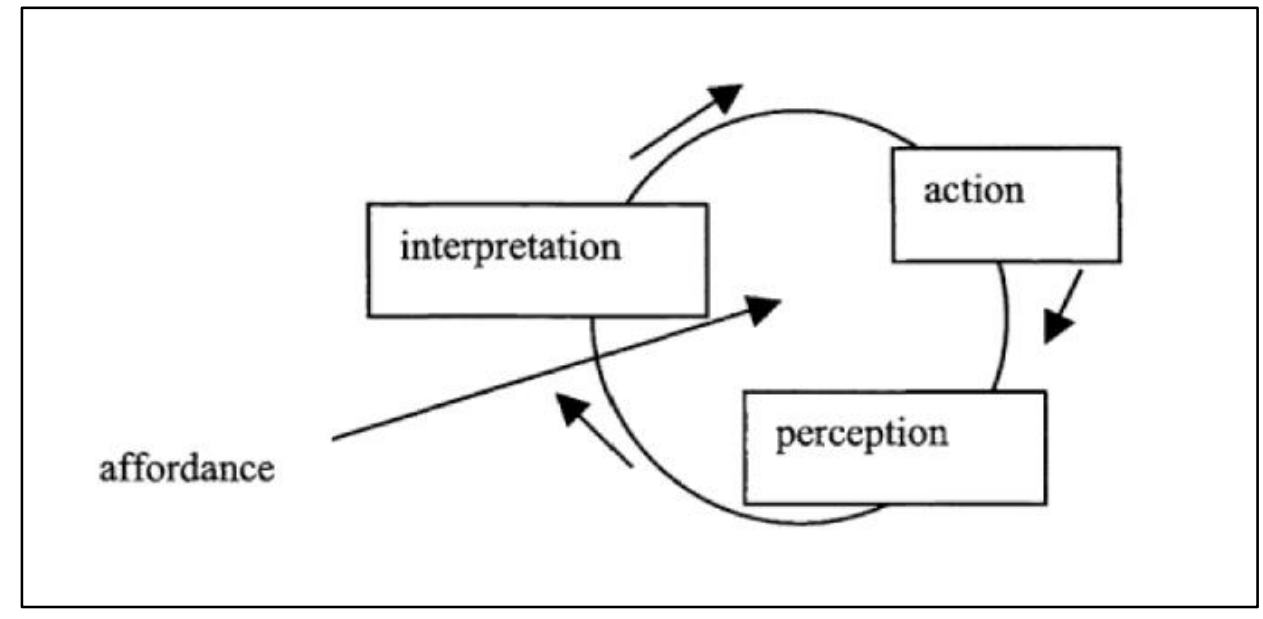

Figure 1 presents the emergence of affordance from individuals' interaction and how they perceive and interpret the environment and take action to meet their needs. Those elements are interconnected and contribute to how each element is functioning. While Kress (2003) identifies that affordance has the potential and limitations of a particular model or medium in 
Nur'Aini, S. University Students' Learning Disruption and Affordance in a Contested Learning Environment

meaning representation and communication, individuals shall be aware of what they can or cannot use to meet their needs and why affordance is essential for their survival. Together, these concepts of affordance offer ideas that it takes both the environment and individuals to navigate how they want to meet their needs for survival in many aspects of life, such as professional or educational needs.

The descriptions above enforce the notion that individuals cannot be separated from society and the affordance it provides. They go hand-in-hand that the connection between what individuals need and their role in the environment shape the society itself, such as the family, class system, and the economy. Within the educational context, society plays a critical role in shaping how individuals perceive their environment and what it offers and how individuals' action and choices can bring about changes in their education and the outcomes (Swift, 1969). Under the context of a contested environment due to COVID-19, learners were forced to change the way they practice their learning because their society only offered so much within the limited circumstances. Together with the affordances that the society and environment offered, the learners were demanded to be flexible and adept at adjusting their ways of learning and communicating with others to fulfil their learning needs.

There is a growing body of literature that recognizes the importance of affordance. Wilkesmann and Lauer (2020) point out that affordances are the features of an artefact that defines how and if a specific learning behavior can be acted upon in defined settings. The thing that is available and how individuals use that affordance is connected to "the relationships between the properties of an educational intervention and the characteristics of the learner that enable particular kinds of learning by him/her (Kirschner, 2002, p. 19). This is consistent with Van Lier's (2004) depiction and categorization of affordance, which will be used as a reference point in this study. The educational context is suitable for this paper's central issue as the situation and context contribute to how affordance relates to the participants' learning experiences. Therefore, from the many definitions of affordance, it can be concluded that affordance is an independent element in a human's life. It is not affected by the environment or changes, as affordance is the environment itself. Individuals need to adjust their actions, perception, and interpretation of their circumstances if they want to manage or survive the environmental changes.

Existing research recognizes the critical role of affordances in academic contexts. Arenas (2015) conducted a study on a higher education context where affordance in learning technology is prominent in students' learning experiences. It elaborates how the teachers' perception should be addressed less than that of the students to explore the benefit of the student-centric perspective. The work of Arenas (2015) considers that affordances in student-centric approaches offer agency in students in determining the pace of their study. This agency is critical as it explores their thoughts and ideas of what and how students use affordances in their environment. Another study of affordance focused on mobile devices and their relation to learning affordances, as reported by Cochrane and Bateman (2010), where they investigated tertiary students' various course contexts as the means of pedagogical integration. In this study, Cochrane and Bateman (2010) pointed out that affordances help students build and develop their skills in combining the tools to advance their study. 
Nur'Aini, S. University Students' Learning Disruption and Affordance in a Contested Learning Environment

Furthermore, Wijekumar et al. (2006) explained the influence of affordance on K-12 and undergraduate learners' learning outcomes and how they move around their learning challenges. It emphasizes how learners use the learning tools, in this case, a computer, to improve their skills in interactive learning and sharpen their problem-solving tasks. The participants' independence and willingness in the work of Wijekumar et al. (2006) were the keys to showing how affordance played a significant role in their learning.

Together, these studies discussed affordance where the use of technology for learning was voluntary, and all means were prepared. They were supported by their environments, such as steady internet connection and learner's willingness to do online learning (Weidlich \& Bastiaens, 2019) and their strong motivation (Setiyadi \& Sukirlan, 2016; Tarhan \& Balban, 2014). Although they have issues with their tools and multimedia contents (Sancristobal et al., 2012), they were not unmotivated because those situations provide affordance that learners can utilize to meet their learning needs. Learners were vigilant to pursue their learning because it was easier for them to manage their lives to adjust with their activities, other learning availability, and availability of teachers (Stone, 2019). Taken together, these studies on online learning affordance, the relative importance of learning facilities, learner's agency, and a country's infrastructure have been the supporting factors for successful online learning.

However, the situation of online learning in a developing country is different. Existing studies discuss common challenges such as infrastructure, learning facilities, and teachers' competence (Crews \& Parker, 2017; Elwood \& MacLean, 2009; Ismail \& Jarrah, 2019; Weston, 2020; Wuttke \& Seifri, 2017). In terms of infrastructure, the online platform becomes a nuisance when implemented in developing countries, as elaborated in the work of Heeks (2002). Some studies explore how online learning is conducted on different platforms that do not require face-to-face meetings between learners and teachers (Lindgren \& McDaniel, 2012; Owen et al., 2020; Persada et al., 2020; Queiros \& de Villiers, 2016). There are influential elements that getting connected becomes a challenge when the hindrances are environmentally unavoidable, as Elwood and MacLean (2009) explained, strengthening the point that a contested environment could exist for a length of time. Depending on how the society that lives within the environment, the learning activities will move around what is available for the learners, such as the shortages of skillful teachers and lack of training centers for teachers, such as in countries like Cambodia who did not have enough teachers who were good with computer and information technology (Crews \& Parker, 2017). Heeks (2002) reports on various issues in countries like South Africa, Thailand, and remote areas in China.

Those existing accounts discuss facilities and teachers' competence, environmental challenges. However, a few have discussed the ways students cope with and navigate around the changes of social and environmental elements of their studies that have significant effects on their learning. In the pages that follow, this paper aims to assess what types of learning affordances were available within the contested environment because of COVID-19 and how they adapt to the changes in their society and environment to overcome their learning challenges. 
Nur'Aini, S. University Students' Learning Disruption and

Affordance in a Contested Learning Environment

\section{Methods}

\section{Design: A case study}

A qualitative research approach (Dörnyei, 2007; Lichtman, 2013) in which this study was framed was employed to explore the participants' points of view. Case studies have been long established to present a detailed analysis of data (Creswell, 2013). As Yin (1994) explains, case study research provides a space for in-depth accounts about a case occurring in a real-life situation. This article adopted the design to provide deep understanding of the participants' narratives.

\section{Participants}

The participants for this cohort were 136 Indonesian university students in the first, second, and third-year during the first semester of 2020, majoring in English education and literature. The sample was representative in terms of gender and the level of their semesters. The author's choice to use an online platform restricted participants' range only to those who had access to the internet. Participants' demographics are elaborated on in Table 2.

Table 2. Participants Demographics Based on Gender and Campus Locations

\begin{tabular}{lllll}
\hline \multirow{4}{*}{ Sex } & \multicolumn{2}{c}{ City names } & & \\
\cline { 2 - 4 } & Semarang & Yogyakarta & Solo & \\
\hline Male & 38 & 16 & 12 & 66 \\
Female & 31 & 15 & 24 & 70 \\
\hline
\end{tabular}

To ensure human ethics regulation was implemented in this study, information sheets and consent forms were shared to get the written agreement that their participation was informed and voluntary. The participants were invited to read the information and purposes on the first page of the online survey. If they did not agree to participate, they could opt out and exit the page. If they consented, they were directed to the pages to answer the survey's main questions. All names included in the narratives were pseudonyms.

\section{Instruments}

In this present case study, data were collected using a web-based survey and language processing to dig deeper into the participants' realm to understand their experience. Using a Google Form survey, the participants were asked to respond to 15 open and closed questions. The close-ended question design of the survey was based on the need to find out the participants' gender, age range, location, and in what semester they were. Meanwhile, the open-ended questions provided a space for the participants to elaborate on their ideas, opinions, and feelings based on the survey questions, thus enabling the author to analyze the survey's narrative aspects. 
Nur'Aini, S. University Students' Learning Disruption and Affordance in a Contested Learning Environment

\section{Data Collection}

Data collection was conducted during the first semester of 2020. The survey was shared through various social media platforms such as WhatsApp, Facebook Messenger, Line, and emails.

\section{Data Analysis Technique}

Data analysis was conducted based on the conceptual framework proposed by Dey (1993) by using the process to describe and classify the phenomenon and perceive how the events and circumstances were interconnected. One of the initial ways to have an understanding of something is through a description. Thick description represents a comprehensive elaboration of an event or a phenomenon. It is more than just stating a fact, but a more detailed presentation of the research contexts. Denzin (2017) adds another thing to help with qualitative analysis: the situation where the research is taking place, or contexts. It covers more than just the location or situation, but sometimes, it presents the historical or social settings. Context provides an understanding of why an action is done under certain circumstances. Dey (1993) underlines the importance of context because it holds meaning, and meaning can be understood when the relevant context is elaborated. The analysis process follows the depiction in Dey's (1993) design that displays the connection between the three elements of a circular process in qualitative analysis.

Figure 2. Qualitative analysis as a circular process (Dey, 1993, p. 32)

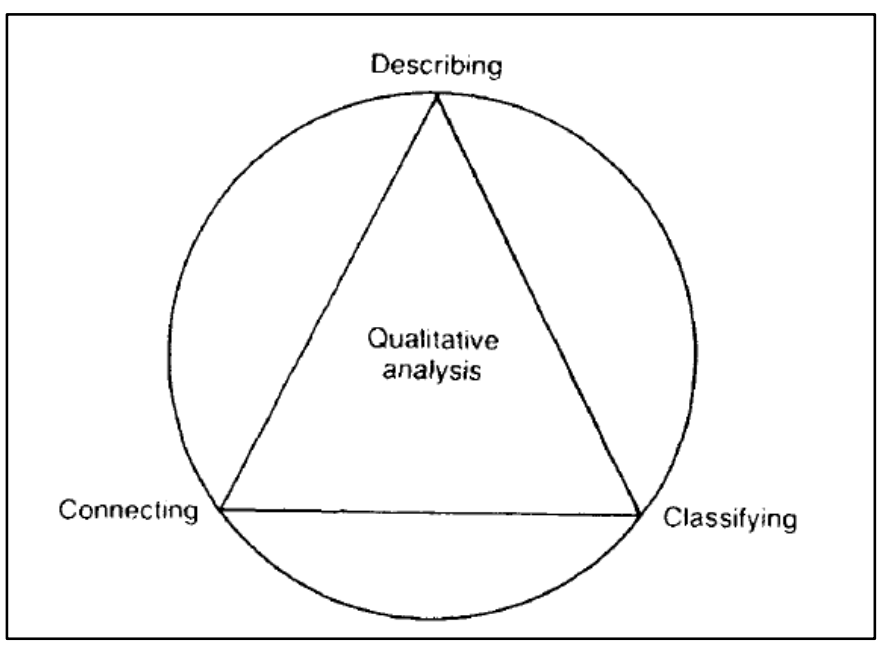

From the questionnaire results, the author read the questionnaire responses from the participants, then group them based on these categories: internet affordance, assignment affordance, and domestic affordance. These three themes were the most commonly found in the participants' narratives. The author then connected the theme to the level of affordance, as indicated in Table 1 above. These steps ensured robust and rich descriptions about how and what affordances were available to the students and how they navigate their learning to deal with the pandemic. The last step of the analysis was connecting the dots of description and classification. It was then followed by seeking the relationship between the research 
Nur'Aini, S. University Students' Learning Disruption and

Affordance in a Contested Learning Environment

components, such as the location of participants' residences and their situation at home, or the challenges related to their learning.

\section{Findings}

This present study answered two research questions: 1) the types of affordances available within the contested environment because of the COVID-19 pandemic and 2) how the participants adapt to the changes in the society and learning contexts to overcome the learning challenges. This Findings section focuses on answering the research questions written in two parts. The first part was the affordances available to the participants during the COVID-19 pandemic, followed by the actions, choices made, and strategies that the participants did to adapt to the changes in society and their learning contexts.

Gibson (2015) stated earlier in this article that environment and context became the essential factors of affordance perceived from the participants' narratives. As stated in the introduction, students were sent home for their safety. Initially, they were happy because this meant they could 'enjoy' time with their families. However, the feeling changed when their university leaders informed that the time they had to spend at home was prolonged indefinitely, and learning was moved to online platforms. The earlier parts of this article mentioned that the transformation from offline to online learning caused turmoil and confusion because everything was uncertain (Garcia-Morales, 2021). They had to follow the teachers who conducted the classes through video conferences, WhatsApp group chat, LMS, and other platforms in their learning process. The lecturers sent the learning materials, assignments, or quizzes through online platforms to allow students to learn independently and asynchronously. Most lecturers chose this method over conducting the class synchronously because of the challenges with the network issues, which was a common experience in developing countries like Indonesia, as explained by Heeks (2002).

The part below elaborates the affordances available in the environment and how the participants responded to the changes. There are four major themes of affordances emerging from the participants' responses to the survey.

\section{Internet Affordances}

Many participants expressed their concern due to the change of learning style, which had caused them to experience distress. The majority of the participants agreed that internet connection was the biggest challenge, as expressed by one of the participants who lived near Blora Regency, one area closest to Semarang in Central Java. This region consisted of hilly areas with numerous small forests, which caused it to have an unstable internet connection. Hardi (pseudonym) shared his challenging experience to access the internet:

I often have a problem getting the internet signal and finding a place to access the class because my parents' house is far from the city. I have to spend a lot of money to buy data. (Hardi, male, 20 y/o - Blora, Semarang area).

These situations and contexts were labelled as internet affordances related to internet signal or the lack thereof. As defined in Van Lier's work (2004) that the disconnected or unmediated 
Nur'Aini, S. University Students' Learning Disruption and Affordance in a Contested Learning Environment

attachment between the participants and the environment occurred in the evidence. They did not know yet how to overcome the issue because they did not have the experience. The sentiment was shared by $54,7 \%$ of the participants as shown in Figure 3.

Figure 3. Challenges of online learning as responded by participants

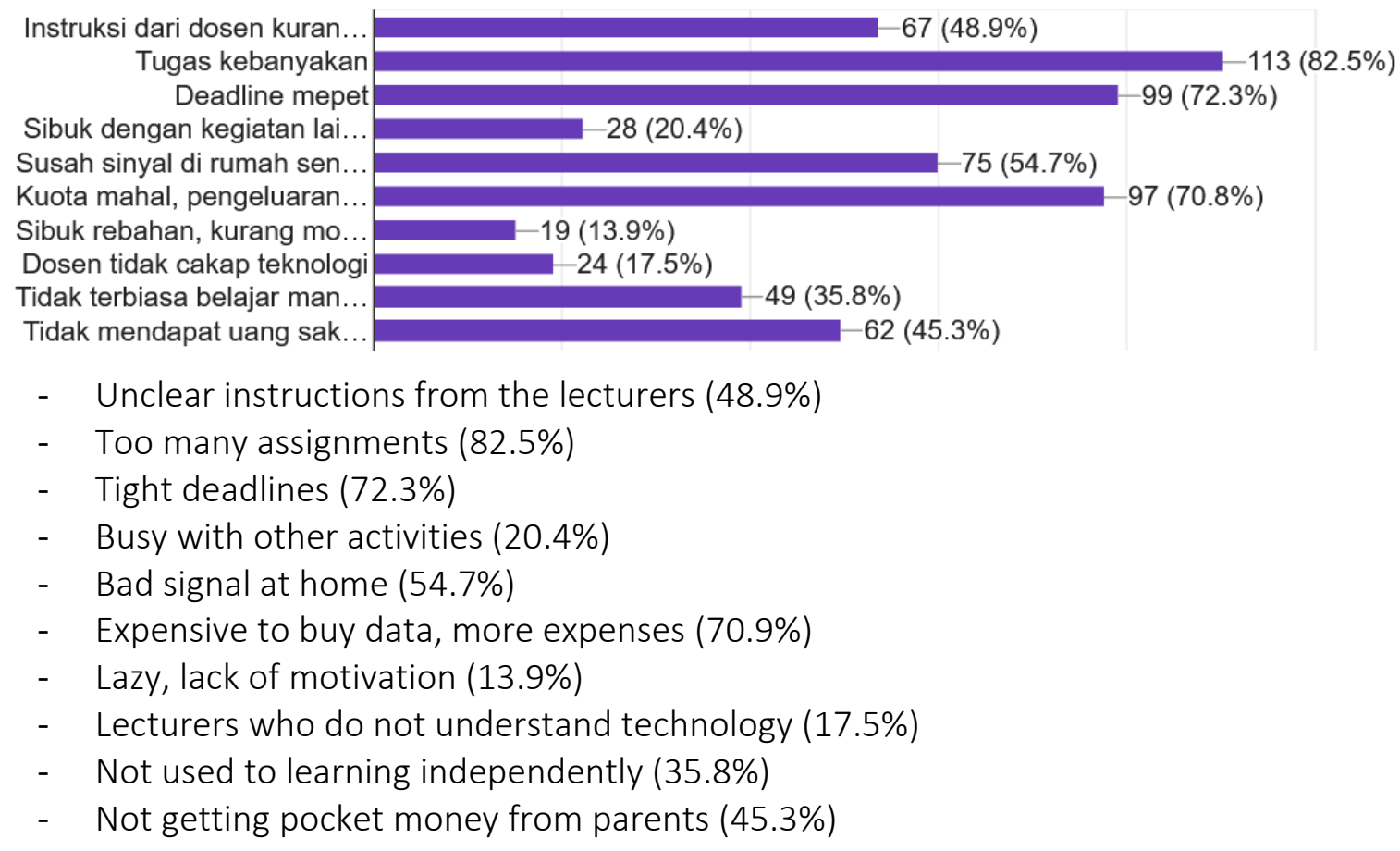

In the places where they lived, internet access could be scarce due to distribution disparity. Although internet providers were competing to provide internet to the people, urban areas likely had a better signal, contrary to remote areas. The participants overcome the issue of internet scarcity in several ways.

One of the surprising things from the students was how swift they adapted to the changes and adjusted their actions to the situation. To accommodate their needs of the internet to complete the assignment from their lecturers, the participants narrated their actions below:

What kind of learning strategies you did to complete the assignments from the lecturers? Share here.

I go to places with internet access, although it is far from home, and stay in that place until the lectures are completed. (Danang, male 21 y/o, Solo area).

In a similar vein, another participant expressed:

It is not easy to get an internet signal at home because my village is in a remote area, in a mountainous region. If I wanted to get a better signal, I have to go to the city, and it took me around 15 minutes of the trip. (Anggun, female $19 \mathrm{y} / \mathrm{o}$, Semarang area) 
Nur'Aini, S. University Students' Learning Disruption and

Affordance in a Contested Learning Environment

Both accounts indicated that the participants chose to go to places where the internet signal was available because it was not available at home. Another action the participants did to access the internet was by providing it for themselves. This statement was similar to Chogyel et al. (2021), who focused on the challenges of online learning for middle school learners. A participant under the pseudonym Putri (female, 20 y/o) stated that:

When I have quota (of internet data) I must save it and prioritize to use it to access important things (assignments). (Putri, female 20 y/o, Semarang area).

Putri only used her data for important things such as her assignments over other things. Both accounts indicated their understanding of Level 2 of Van Lier's affordance, where they recognized the challenges and engaged with them to figure out how to overcome the issues. The challenges that the participants encountered related to providing the internet for their learning is also found in Jaradat and Ajlouni (2021), who worked on the perspective of undergraduate students on online learning.

\section{Assignment Affordances}

Concerns regarding assignments from the lecturers were the second most expressed by the participants. The added workload to work independently added to the internet network problems above. One of the participants wrote her concern related to the changes in assignment workload:

We get so many assignments with tight deadlines that make me feel so stressed and want to give up working on the assignments, and I am not used to studying alone at home because I usually discuss the lessons with my friends and lecturers. (Nilan, female, 21 y/o- Solo area).

This account indicated the first level of affordance in Van Lier's work as it expressed the stress and desperation in dealing with assignments. The overwhelming feelings of loneliness because Nilan was not used to studying by herself. Besides the loneliness, other issues emerging from the participants' narratives were about the number of assignments they had to complete:

For example, one assignment was completed, and there are 2345678 more assignments even though I just finished one assignment, there are more to come] (Priyo, male, 19 y/o, Semarang area).

In dealing with the number of assignments in a day, the participants sorted their priorities of the assignments by the closest deadlines was the emerging theme coming from the participants. They began to understand Level 2 of Affordance by engaging it to meet their needs. The narratives below are the examples of how they manage their academic activities:

I will do my best to complete the assignments, and when the lecturers did not give the materials thoroughly, I usually used Google to search for more materials or study independently from the books. If I still get difficulties understanding it, I will ask my friends, and we study together. (Susianti, female, 20 y/o Solo area).

The challenges were not only the internet connection, but also on the incomplete learning materials they got from their lecturers. Participants were conditioned to be independent in finding more explanations. It was difficult because they did not have the channel to express 
Nur'Aini, S. University Students' Learning Disruption and

Affordance in a Contested Learning Environment

their curiosity. Therefore, they sought cooperation with their classmates to discuss the materials together. In a similar vein, the narrative from Yanto strengthened the point of the necessity of working with classmates.

When a lecturer gave an assignment, if I understood it, I would do it immediately. However, if I had problems with the materials and assignment, I will ask my friends. If we both didn't understand it we discussed it by inviting other friends to form a WhatsApp group for each subject and inviting the lecturer to discuss the materials together. (Yanto, male, 19 y/o, Yogyakarta area).

The responses to the assignment affordance that initially put them in an overwhelming state because they did not know yet how to organize their time and set their priority. As time went by, they became more adept at adjusting to the environment. They showed their understanding of Level 2 of affordance where they responded to the environment to benefit themselves. Setting up priorities, making a list, making a schedule, and communicating with their friends through an online messaging platform such as WhatsApp. Since the online learning made it hard for them to engage with their friends in real-time, they showed an understanding of the third level of affordances in Van Lier (2004) as they began to take actions to overcome the stress by sharing the burden with their friends to make sure that their lecturers' demands were met. Several participants expressed that they acquired new skills in using the internet concerning their assignments such as choosing the right keywords and mining information from websites to add the reference of their works.

\section{Domestic Affordances}

Several participants were particularly critical about their domestic situation. Their narratives indicated that the prolonged time of learning at home had become a seed for challenges and misunderstanding among family members. Below is the excerpt of the concerns:

My parents are not happy that I spent much time on my phone or laptop. They thought I was playing games and did not want to help around the house while doing the online classes. (Damian, male 19 y/o - Yogyakarta area).

The online classes required students to spend most of their time on their devices to access the learning materials. The number of classes they had to participate in determined how long they needed to be on their devices. This choice of actions resulted in a lack of contribution to do the house chores and spend with their family members. Furthermore, some parents did not comprehend online learning, which led them to think that their children were spending time outdoor for fun or playing with their phones and caused them to become cross with their children. Their understanding of Level 3 of Van Lier's affordance, where they engaged with the domestic concerns and adjusted their activities to avoid confrontation with their parents.

Usually, I finished my house chores in the morning so that I could focus on completing my campus assignment. However, it is not always like that because during the lecture, or when I am doing the assignment, my parents or family members ordered me to do something. (Sabrina, female, 21 y/o, Semarang area). 
Nur'Aini, S. University Students' Learning Disruption and

Affordance in a Contested Learning Environment

Doing house chores was inevitable for some participants because it was considered an obligation to help their parents. They needed to navigate between doing the online class and meeting their domestic obligation to their families. Another participant expressed how misunderstanding with his parents often occurred because of the online classes. Hilman explained how he overcame the challenges in the narrative below:

When we are at home, house chores are inevitable. It feels awkward because I had to choose the online class while at the same time, my parents asked me to help them. It often became a cause of arguments because of misunderstanding. Usually, I helped them first, then joined the class. (Hilman, male, $20 \mathrm{y} / \mathrm{o}$, Yogyakarta area).

Hilman's action indicated his understanding of the affordance where his parents did not understand how the online course was conducted. Hilman chose to do the house chores before he participated in the online class. The strategy he did to overcome the issue was supported by a statement from another participant who opted to move all his gadgets in the living room so that everyone in the family could see what he did.

When I do the assignment or join online class, I don't do it in my bedroom and stay away from the bed because potentially I will be lying down and be lazy. I do my assignment and classes on my desk in the living room so that the people at home can see that I am joining a class and not playing games. (Wawan, 19 y/o, Semarang area).

The temptation of being lazy when working in the bedroom was a challenge that Wawan tried to avoid. He showed his understanding of Level 2 of affordance where they realized the presence of affordance and engaged with it. By sitting in the living room where everyone could see their activities, Wawan completed the two challenges of doing his online classes and keeping his family informed about his activities. They were aware of the issues and recognize that their parents were not on the same page of understanding how online learning was conducted, and they helped their parents understand their challenges.

\section{Distance Learning Affordances}

Amidst the frustration that came with the transition to online learning, many participants highlight the positive and beneficial things about distance learning. They shared the sentiment about transportation changes as quoted below:

Besides the unpleasant things, I feel some positive things, such as saving my fuel money because the trip from my house to campus is quite far, and it saves my energy, and this online class is indeed more flexible. (Debbie, female, $21 \mathrm{y} / \mathrm{o}$ Semarang area)

Out of all the aspects of studying online, Debbie took the positive aspect of it. Debbie's narrative is consistent with the findings in the work of Weidlich and Bastiaens (2019), particularly in the part where she did not have to move places to study. The situation meant that they did not have to worry about getting caught in the rain and traffic or coming late to class. Furthermore, by having the classes at home, they did not have to spend their money to buy food because the parents provided the meals. Another thing that was advantageous to the participants was that 
Nur'Aini, S. University Students' Learning Disruption and

Affordance in a Contested Learning Environment

distance learning allowed them to be more productive because they did not spend time traveling. The positive aspect of online learning was not limited to the lack of necessity to travel and other things such as increased independence among the participants.

My biggest motivation is to become independent without the explanation from the lectures, I must be independent to find information when the lecturers only gave me the assignments without any explanation beforehand. I did various things to complete an assignment. (Hermina, female, 21 y/0, Solo area).

Online learning brought positive changes in the participants. Their independence became the most significant change in the way they conducted learning. Before the pandemic hit, they depended on the lecturers to provide the learning materials and information in the classroom. However, as they were faced with an urgent situation, they changed their learning behavior. The participants utilized their resources such as laptops and internet access to search for additional information about their learning subjects. They became more independent and selfreliant to accommodate their learning needs.

This article has responded to two research questions and the affordances came down into four categories as elaborated above. In each category, the participants' ways to adapt to the changes have been provided and explained.

\section{Discussion}

The findings support the premise that affordance is influenced by the environment where the participants live. The quick changes in the environment and people's behavior allow the participants to choose when the needs arise. They overcome issues from internet problems to negotiating activities with their parents and gaining independence in their learning. It shows how participants controlled their actions even when the circumstances did not provide support for them. Their creativity and perseverance would not have shown up most interestingly if the situation had not been demanding like that. For example, the internet in Indonesia could be traced back to the early '90s, but online learning was never a main option until the pandemic strikes. This essential change in behavior suggests that when the environment forces the people living in it to change, they do it for the sake of survival, education, and other urgent needs (Chiu et al., 2021).

The key strength of this present study was the actions and strategies of the participants in responding to the affordance that their environment offered. Some of the issues emerging from the findings relate specifically to the participants' independence. In the usual context preCOVID, most Indonesian students were used to the instructions from their lecturers given in the classroom. Unfortunately, the instruction was not always available, either because the lecturers did not share it or the students were troubled by their internet connection. However, the participants found a way to manage this challenge by searching for more information online for the topics that were not elaborated in detail. This finding has a similar vein with the work of Colombari et al. (2021) who wrote about self-determined learning to emphasize on the participants' independence. They learned more through their independent study and discussion with their peers through online chats or emails. They became a better learner even 
Nur'Aini, S. University Students' Learning Disruption and

Affordance in a Contested Learning Environment

when their environment limited their access to face-to-face meetings with their lecturers. They managed their priorities, took regular breaks, cut the hours spent on social media, and allocated their data mainly for their learning needs.

The impact of online learning was directly affecting their English learning that required practice and spoken communication. The participants who lived in a society with poor internet connections were challenged by the delivery of learning materials from the lecturers. It frequently occurred that during the lesson, the lecturer's voices were interrupted, unclear, or disconnected entirely, making learning impossible. This phenomenon of internet connection problems is also found in the studies by Atmojo and Nugroho (2020); Ilmi Zajuli et al. (2020); Pajarianto et al. (2020). The participants, family members, lecturers, and everyone else involved in online learning indicated how they struggled to cope with the challenges in learning, providing for the family, and staying healthy and safe for everyone affected by the COVID-19. This situation is relevant to the challenges of online learning described in the work of Heeks (2002). As for the challenges with their English practices, they formed group chats to practice with their friends online. However, this method of practice was found as impractical, exhausting, and time-consuming, while it yielded very little success to improve their skills in speaking or listening, which is also found in the work of Subekti (2021). In spite of its limitation, this study adds some insight to the independence of Indonesian university students which was often overlooked by the lecturers and by the students themselves. They were not aware that they could achieve that level of independence in managing their time, learning activities, and research skills. However, the findings have shown that they were capable of being independent when they need to be, and it was a refreshing knowledge to learn.

\section{Conclusion and Implications}

There are four kinds of affordance emerging from this study: internet affordance, assignment affordance, domestic affordance and distance learning affordance. The first thing the participants did to adjust to the changes is by changing their online behavior and actions to fulfill their learning needs. They worked with their friends and set priorities to ensure that they completed the assignments. The findings indicate that affordances are flexible and difficult situations can trigger creative thinking and actions. Affordance is independent regardless of the circumstance, while the participants are dependent on the circumstance. Its independence does not change because a person does not like the circumstance that triggers the emergence of affordance. The way individuals respond to affordance will determine how they carry out their actions because how the participants react, think, and behave is influenced by their environment.

Hardship in life always comes in many forms; however, adapting and using the circumstance to benefit the individuals depend on familiarity, experience, and adeptness in dealing with the challenges. They could use it to benefit from the circumstances or succumb and give up on the situation. This study proves that students are resilient and creative. With the help from the people around them, such as family members, lecturers, and peers, they could tackle online learning challenges that they have not done before. They managed to face, deal with, and control the affordance available to them in the middle of their learning challenges. 
Nur'Aini, S. University Students' Learning Disruption and Affordance in a Contested Learning Environment

The implications of this study can be applied in how other studies focus on how lecturers deal with online teaching. A few of the participants indicated that some senior teachers have difficulties migrating from offline to online teaching. The lecturers' challenges in using technology, gadgets, and internet platforms had caused a disturbance in the learning process because the lecturers could not provide materials on the online platform. Other aspects of the study that can be investigated within this COVID-19 context are teachers and students' motivation, agency, and emotion.

The present study was subject to several potential methodological weaknesses. Data was collected through anonymous online survey, which did not allow clarification from the participants. It resulted in the limited information asked and responded to by the participants. Although the study has successfully demonstrated how participants employed affordances, the perspective of how data was view could limit the elaboration of analysis. Lastly, the generalizability of the results might not be repeated elsewhere because of the specific nature of the participants who experienced the changes of learning platform at the beginning of the pandemic.

\section{References}

Arenas, E. (2015). Affordances of learning technologies in higher education multicultural environments. The Electronic Journal of e-Learning, 13(4), 217-227.

Arthur-Nyarko, E., Agyei, D. D., \& Armah, J. K. (2020). Digitizing distance learning materials: Measuring students' readiness and intended challenges. Education and Information Technologies: The Official Journal of the IFIP Technical Committee on Education, 1(16), 1-16. https://doi.org/10.1007/s10639-019-10060-y

Atmojo, A. E. P., \& Nugroho, A. (2020). EFL classes must go online! Teaching activities and challenges during COVID-19 pandemic in Indonesia. Register Journal, 13(1), 49-76. https://doi.org/10.18326/rgt.v13i1.49-76

Chiu, T. K., Lin, T.-J., \& Lonka, K. (2021). Motivating online learning: The challenges of COVID19 and beyond. Asia-Pacific Educational Research, 30(3), 187-190. https://doi.org/https://doi.org/10.1007/s40299-021-00566-w

Chogyel, N., Wangdi, N., \& Dema, Y. (2021). Evaluating the challenges in online learning during the COVID-19 pandemic in a middle secondary school. International Journal of Didactical Studies, 2(2), 1-9. https://doi.org/https://doi.org/10.33902/IJODS.2021269731

Cochrane, T., \& Bateman, R. (2010). Smartphones give you wings: Pedagogical affordances of mobile Web 2.0. Australasian Journal of Educational Technology, 26(1), 1-14. https://doi.org/http://dx.doi.org/10.14742/ajet.1098

Colombari, R., D'Amico, E., \& Paolucci, E. (2021). Can challenge-based learning be effective online? A case study using experiential learning theory. CERN Idea Square Journal of Experimental Innovation, 5(1), 40-48. https://doi.org/https://doi.org/10.23726/cij.2021.1287

Creswell, J. W. (2013). Qualitative inquiry \& research design: Choosing among five approaches (3rd ed.). SAGE Publications. 
Nur'Aini, S. University Students' Learning Disruption and Affordance in a Contested Learning Environment

Crews, J., \& Parker, J. (2017). The Cambodian experience: Exploring university students' perspectives for online learning. Issues in Educational Research, 27(4), 697-719.

Daumiller, M., Rinas, R., Hein, J., Janke, S., Dickhäuser, O., \& Dresel, M. (2020). Shifting from face-to-face to online teaching during COVID-19: The role of university faculty achievement goals for attitudes towards this sudden change, and their relevance for burnout/engagement and student evaluations of teaching quality. Computers in Human Behavior, 118, 1-38. https://doi.org/10.1016/j.chb.2020.106677

Denzin, N. K. (2017). The research act: A theoretical introduction to sociological methods (1st ed.). Taylor and Francis.

Dey, I. (1993). Qualitative data analysis: A user-friendly guide for social scientists. Routledge.

Dörnyei, Z. (2007). Research methods in applied linguistics: Quantitative, qualitative, and mixed methodologies. Oxford University Press.

Elwood, J., \& MacLean, G. (2009). ICT usage and student perceptions in Cambodia and Japan. International Journal of Emerging Technologies \& Society, 7(2), 65-82.

Garcia-Morales, V. J. G.-M., Aurora Martin-Rojas, Rodrigo. (2021). The transformation of higher education after the COVID disruption: Emerging challenges in an online learning scenario. Frontiers in Psychology, 54(1), 46-57.

Gibson, J. J. (2015). The ecological approach to visual perception (Classic edition ed.). Psychology Press \& Routledge.

He, W., Xu, G., \& Kruck, S. E. (2014). Online IS education for the 21st Century. Journal of Information Systems Education, 25(2), 101-105.

Heeks, R. (2002). Information systems and developing countries: Failure, success, and local improvisations. Information Society, 18(2), 101-112.

https://doi.org/10.1080/01972240290075039

Ilmi Zajuli, I., Henita, R., Agung, P., Diana Vivanti, S., Edi, K., Aryani Kadarwati, D., Nina, W., Farah Muthi, H., \& Giry, M. (2020). COVID-19 dan e-learning: Perubahan strategi pembelajaran sains dan lingkungan di SMP. JINOP (Jurnal Inovasi Pembelajaran), 6(1), 50-61. https://doi.org/10.22219/jinop.v6i1.11791.

Ismail, S. A. A., \& Jarrah, A. M. (2019). Exploring pre-service teachers' perceptions of their pedagogical preferences, teaching competence and motivation. International Journal of Instruction, 12(1), 493-510. https://doi.org/10.29333/iji.2019.12132a

Jaradat, S., \& Ajlouni, A. (2021). Undergraduates' perspectives and challenges of online learning during the COVID-19 pandemic: A case from the university of Jordan. Journal of Social Studies Education Research, 12(1), 149-173.

Kalimullina, O., Tarman, B. \& Stepanova, I. (2021). Education in the Context of Digitalization and Culture: Evolution of the Teacher's Role, Pre-pandemic Overview. Journal of Ethnic and Cultural Studies, 8(1), 226-238. DOI: http://dx.doi.org/10.29333/ejecs/629

Kidd, T. T. (2010). Online education and adult learning: New frontiers for teaching practices. IGI Global.

Kirschner, P. A. (2002). Can we support CCSL? Educational, social and technological affordances the public acceptance of the professorship in Educational Technology, Den Haag, NL.

Kress, G. R. (2003). Literacy in the new media age. Routledge. 
Nur'Aini, S. University Students' Learning Disruption and Affordance in a Contested Learning Environment

Laurillard, D. (2002). Rethinking university teaching: A conversational framework for the effective use of learning technologies (2nd ed ed.). Routledge \& Falmer.

Li, C., \& Lalani, F. (2020). The COVID-19 pandemic has changed education forever. This is how https://www.weforum.org/agenda/2020/04/coronavirus-education-global-covid19online-digitallearning/?fbclid=IwAR2OGpCPoazP34Q0teND6Z6ukHvRuaILTDvAjawCctrxUJwO5a8BT dC8Kp8.

Lichtman, M. (2013). Qualitative research in education: A user's guide (3rd ed.). SAGE Publications.

Lindgren, R., \& McDaniel, R. (2012). Transforming online learning through narrative and student agency. Journal of Educational Technology \& Society, 15(4), 344-355.

Liu, L., Liu, K., \& Zhao, J. (2020). Development of online flipped blended teaching mode in higher vocational education during COVID-19 outbreak: A case study. In (pp. 193-198): IEEE.

Mueller, R. J. (2018). Principles of classroom learning and perception. Routledge.

Norman, D. A. (2002). The design of everyday things (Vol. 1). Basic Books.

Nyoni, J. (2014). E-readiness of open and distance learning (ODL) facilitators: Implications for effective mediation. Perspectives in Education, 32(3), 78-91.

Owen, S., White, G., Palekahelu, D., Sumakul, D. T., \& Sekiyono, E. (2020). Integrating online learning in schools: Issues and ways forward for developing countries. Journal of Information Technology Education, 19, 571-614. https://doi.org/10.28945/4625.

Pajarianto, H., Kadir, A., Galugu, N., Sari, P., \& Februanti, S. (2020). Study from home in the middle of the COVID-19 pandemic: Analysis of religiosity, teacher, and parents support against academic stress. Talent Development \& Excellence, 12(2), 1791-1807.

Palvia, S., Aeron, P., Gupta, P., Mahapatra, D., Parida, R., Rosner, R., \& Sindhi, S. (2018). Online education: Worldwide status, challenges, trends, and implications. Journal of Global Information Technology Management, 21(4), 233-241.

https://doi.org/10.1080/1097198X.2018.1542262.

Perraton, H. (1985). Alternative routes to formal education: Distance teaching for school equivalency. The Johns Hopkins University Press.

Persada, S. F., Oktavianto, A., Miraja, B. A., Nadlifatin, R., Belgiawan, P. F., \& Redi, P. (2020). Public perceptions of online learning in developing countries: A study using the ELK stack for sentiment analysis on Twitter. International Journal of Emerging Technologies in Learning, 15(9), 94-109. https://doi.org/10.3991/ijet.v15i09.11579.

Pete, J. S. (2020). Crown Point student being kept home because of coronavirus exposure fears. The Times. https://www.nwitimes.com/news/local/crown-point-student-beingkept-home-because-of-coronavirus-exposure-fears/article 5aed8ae8-ae07-56ab95bf-994afb8007e1.html.

Purcell, D., \& Hetrick, C. (2020). Many students are stuck at home without internet after coronavirus closed schools. Philadelphia Inquirer.

https://www.inquirer.com/education/coronavirus-students-digital-dividephiladelphia-comcast-20200403.html.

Queiros, D. R., \& de Villiers, M. R. (2016). Online learning in a South African higher education institution: Determining the right connections for the student. International Review of 
Nur'Aini, S. University Students' Learning Disruption and Affordance in a Contested Learning Environment

Research in Open \& Distance Learning, 17(5), 165-184.

https://doi.org/10.19173/irrodl.v17i5.2552.

Rapanta, C., Botturi, L., Goodyear, P., Guàrdia, L., \& Koole, M. (2020). Online university teaching during and after the COVID-19 crisis: Refocusing teacher presence and learning activity. Postdigital Science and Education. https://doi.org/10.1007/s42438020-00155-y.

Saltiel, D. (2017). Supervision: A contested space for learning and decision making. Qualitative Social Work, 16(4), 533-549. https://doi.org/10.1177/1473325016633445

Sancristobal, E., Pesquera, A., Martín, S., Gil, R., Tawfik, M., Castro, M., Ruiz, E., Díaz, G., Colmenar, A., \& Carpio, J. (2012). Challenges of applying online learning tools in distance learning courses. Proceedings of the 2012 IEEE Global Engineering Education Conference (EDUCON), Marrakech, Morocco.

Setiyadi, A. B., \& Sukirlan, M. (2016). Language attitude and motivation of the Islamic school students: How madrasa students of the academic year 2013-2014 in Indonesia perceive English, English teaching and learning and native speakers of English. Pertanika Journal of Social Sciences \& Humanities, 24(1), 331-350.

Sohrabi, C., Alsafi, Z., O'Neill, N., Khan, M., Kerwan, A., Al-Jabir, A., Iosifidis, C., \& Agha, R. (2020). World Health Organization declares global emergency: A review of the 2019 novel coronavirus (COVID-19). International journal of surgery, 76, 71-76. https://doi.org/10.1016/i.ijsu.2020.02.034.

Subekti, A. S. (2021). Covid-19-triggered online learning implementation: Pre-service English teachers' beliefs. Metathesis: Journal of English Language, Literature, Teaching , 4(3), 232-248.

Stone, C. (2019). Online learning in Australian higher education: Opportunities, challenges and transformations. Student Success, 10(2), 1.

Swift, D. F. (1969). The sociology of education: Introductory analytical perspectives (1st ed.). Routledge. https://doi.org/10.4324/9781315223049.

Tao, X., Linying, J., Xin, Z., Nan, X., \& Lijuan, C. (2016). The transformation of Chinese traditional education: Selected papers by Tao Xingzhi on education. Brill.

Tarhan, H., \& Balban, S. (2014). Motivation, learner identity and language learning. International Journal on New Trends in Education and their Implications (IJONTE), 5, 183-197.

van Lier, L. (2004). The semiotics and ecology of language learning. Utbildning \& Demokrati, 13(3), 79-103.

Vladoiu, M., \& Constantinescu, Z. (2020). Learning During COVID-19 pandemic: Online education community, based on discord. In (pp. 1-6): IEEE.

Wajdi, M. B. N., Kuswandi, I., Al Faruq, U., Zulhijra, Z., Khairudin, K., \& Khoiriyah, K. (2020). Education policy overcome coronavirus, a study of Indonesians. EDUTEC: Journal of Education and Technology, 3(2), 96-106.

Weidlich, J., \& Bastiaens, T. J. (2019). Designing sociable online learning environments and enhancing social presence: An affordance enrichment approach. Computers \& Education, 142. https://doi.org/10.1016/j.compedu.2019.103622. 
Nur'Aini, S. University Students' Learning Disruption and Affordance in a Contested Learning Environment

Weston, H. (2020). The cultural dimensions of information use: A focus on the experience of Emirati students in higher education. Journal of Culture and Values in Education, 4(1), 116-134. https://doi.org/10.46303/jcve.2020.8

White, C. (2003). Language learning in distance education. Cambridge University Press.

White, C. (2014). The distance learning of foreign languages: A research agenda. Language Teaching, 47(4), 538-553. https://doi.org/10.1017/S0261444814000196.

Wijekumar, K. J., Meyer, B. J. F., Wagoner, D., \& Ferguson, L. (2006). Technology affordances: The 'real story' in research with K-12 and undergraduate learners. British Journal of Educational Technology, 37(2). https://doi.org/10.1111/j.1467-8535.2005.00528.x.

Wilder-Smith, A., \& Freedman, D. O. (2020). Isolation, quarantine, social distancing and community containment: Pivotal role for old-style public health measures in the novel coronavirus (2019-nCoV) outbreak. Journal of Travel Medicine, 27(2). https://doi.org/10.1093/jtm/taaa020

Williams, T., McIntosh, R., \& Russell, W. (2021). Equity in distance education during COVID-19. Research in Social Sciences and Technology, 6(1), 1-24. https://doi.org/10.46303/ressat.2021.1

Wilkesmann, U., \& Lauer, S. (2020). The influence of teaching motivation and new public management on academic teaching. Studies in Higher Education, 45(2), 434-451. https://doi.org/10.1080/03075079.2018.1539960

Wong, K. M., \& Moorhouse, B. L. (2020). The impact of social uncertainty, protests, and COVID-19 on Hong Kong teachers. Journal of Loss and Trauma, 25, 649-655. https://doi.org/10.1080/15325024.2020.1776523

Wuttke, E., \& Seifri, J. (2017). Professional error competence of preservice teachers: Eavaluation and support. Springer International Publishing.

Yin, R. (1994). Case study research, design and methods (2nd ed.). SAGE Publications.

Zhu, Q., \& Bingham, G. P. (2010). Learning to perceive the affordance for long-distance throwing: Smart mechanism or function learning? Journal of Experimental Psychology: Human Perception and Performance, 36(4), 862-875.

https://doi.org/10.1037/a0018738 